\title{
THE PREVALENCE OF DIFFERENT TEACHING METHODS IN INCLUSIVE EDUCATION
}

\section{Saša Stepanović ${ }^{1}$}

Elementary School 'Mladost”, Belgrade, Serbia
Original scientific paper

Received: 2019/1/10

Accepted: 2019/3/15

\begin{abstract}
\section{INTRODUCTION}

Teaching methods are the fundamental elements of the teaching process that regulate its course and the activity of its participants in achieving specific goals (Pranjić, 2005; Meyer, 2002). In other words, methods represent the patterns of communication between the teacher and pupils which are adjucted to pupils' characteristics and needs in order to construct knowledge (Buljubašić Kuzmanović, \& Petrović, 2014). The methodological structure and diversity enables learning and makes its acquisiton easier.
\end{abstract}

Teaching methods represent the basic, regulatory elements of the teaching process. The aim of this study was to investigate the prevalence of different methods in inclusive Serbian schools. The sample consisted of 16 elementary schools attended by pupils with sensory impairments (visual and auditory impairments: $N=69$ ). 382 school classes of sixth and seventh grade were systematically observed to register the frequency of method used. Results have shown that the most frequently used method was the monologue (39,7\%) followed by the dialogic method $(39,2 \%)$ while other methods were used far less often (written/graphic presentation (12,3\%), working with text $(5,8 \%)$ and demonstration $(2,8 \%))$. The quality of teaching can be significantly lowered if one method is predominantly used in class. Implications for more effective teaching in inclusive schools are discussed, with special regard to pupils with sensory impairments.

Keywords: inclusive education, dialogic method, monologic method, teaching methods, pupils with sensory impairments

The number and classification of teaching methods vary through the pedagogical literature. In this study, the methods of interest were the monologic method, dialogic method, written/graphic presentation, working with text and demonstration. These methods are most commonly used in Serbian schools and frequently researched in the field. It is important to stress that no teaching method by itself is sufficient to answer the demands of modern education whose emphasis is on the functionality of knowledge. On the contrary, it is the balanced combination of different teaching methods that can appropriately address these demands.

\footnotetext{
${ }^{1}$ Correspondence to:

Saša Stepanoviš, Elementary School 'Mladost", Belgrade, Serbia

Gandijeva 99, Belgrade, Serbia

E-mail: salenono86@gmail.com
} 
The desired outcome of modern education is in line with the trend of inclusion that postulates the equal and active participation of each pupil, regardless of impairments or disabilities. It tends to provide an optimal development of the personality, knowledge and skills for every child, minimizing the negative influence of an impairment for children who have it. Thus, the adaptation to individual differences and the group of pupils implies that one teaching method is far from enough (Walsch, 2002). Inclusive schools and their teachers need to guarantee the adequate support for their pupils, and one of the most relevant aspects of it is a meaningful organization of the class structure (Jablan \& Kovačević, 2008). Traditional schooling often establishes one or two dominant teaching methods (or forms of work) and perpetually relies on them. This can lead to the routinization and formalization of the class, creating an asymmetry in the activity of its agents. Consequently, the quality of learning and communication can notably decrease. For that reason, the implementation of inclusive practice represents a challenge the whole educational system, the teachers and finally, the learning process itself (Booth \& Ainscow, 2010).

It is also important to notice that the application of teaching methods requires certain transformations when pupils with impairments are included in the class, in order to be effective. In this study, the main focus is on children with visual and auditory impairments. Hence, the examples for transformations include: the seating order, which may need to be rearranged, different assisting tools that need to be prepared and correctly used, reformatting the class subject and providing additional attention and support (see Communication Access and Quality Education for Deaf and Hard-of-hearing Children 1999). The achievement of educational goals also depends on the way other pupils perceive difference, which the teacher can greatly influence. When individual differences are accepted, they can become the source for achieving the higher overall quality of class in terms of peer relations, learning and the wellbeing of pupils with impairments. The monologic method is often considered equal to the frontal form of work (ex cathedra), mainly because it rests on the unidirectional communication. The teacher is the most active agent of the class that gives an oral presentation, while pupils remain relatively passive. This method relies on the assumption that the knowledge can be transmitted through listening. Research only partially supports this, suggesting that the monologic method is efficient, but not more efficient than other methods (Bligh, 1998). More specifically, its applica- tion is appropriate when basic information is needed (for example, an introduction to certain material or while making final conclusions) or when new information is introduced. With the use of monologue, the content of the class can be presented systematically, logically and economically, however the quality of its realization is entirely the teacher's responsibility (Terhart, 2001). When pupils with sensory impairments attend class, the teacher needs to consider everything from the seating arrangement, multimedia support, the characteristics of his speech to the proper use of tools (depending on the type of impairment), in order to be certain that the subject is understandable. Yet, when the monologic method is overly used, it can have negative consequences. The aforementioned unidirectionality of communication, regardless of the level of structure the speech has, can distance the teacher from pupils as well as pupils from each other, resulting in the "collective of disconnected individuals" (Watkins, 2005 , p. 21). As such, the monologue can inhibit authentic conversation (Skidmore, 2000) and it can make the learning process severely more difficult and even rigid. Therefore, it is crucial to combine it with other methods than lean on the social aspect of learning.

The dialogic method includes direct, two-way interaction on the pupil-teacher and pupil-pupil relation. It is based on questions, answers and discussion. Its focus on specific goals and the teacher's preparation for discussion separates it from "normal" or "casual" conversation. Sometimes it is regarded as the method of the greatest cognitive potential, because it requires from pupils a deeper level of information processing (Lyle, 2008). Although it can have many different forms and can be used in many settings, its biggest value lies in the social and emotional bondinnng between pupils (Burbules, 1993). Dialogue helps pupils acquire communication skills, giving them the opportunity to explore ideas and question facts (Egan, 1992), enabling the active construction of meaning (Lyle, 2008) and finally, encouraging an accepting atmosphere for pupils with disabilities who feel they can contribute (Alexander, 2006). However, when using this method, it must be ensured that all pupils are prepared and motivated for discussion (Burbules, 1993). The differences in skills, preferences and communication styles can be difficult to handle. Nevertheless, pupils with sensory impairments need to have the opportunity to hear others and be at liberty to state their own opinion or ask questions. Similar to monologue (or any other method), when dialogue is used extensively (especially if the use is improper), it can prove counterproductive and exhaustive. 
The method of demonstration includes additional elements (e.g. using a model, an object, an experiment, a clip showing a process etc.) that serve to prove and/ or clarify the subject of the class. This method is very useful for connecting theory to practice, or when the theory is too abstract or difficult for pupils to understand (Freire, 2000). Demonstration activates pupils in a way that enables them to try out what the teacher is doing or talking about (for instance, in the laboratory), thus reinforcing their knowledge. It has a great potential because it can cover a variety of class material. Even the discussion can be classified as a demonstration if it is used for the purpose of learning what discussion is and how it is used (Hoover, 1958). When pupils have the task of demonstrating something as a group, the demonstration method gains the value of the dialogic method as well in terms of socialization. In its implementation it is important to take into account the level of knowledge pupils already have and individual capabilities in relation to the task (Glasson, 1989). Moreover, the teacher needs to accurately assess the usefulness of demonstration when considering the specific goal of the class, i.e. judge whether it will be clear to everyone and is it better to use a different method for the same purpose.

Acquiring knowledge through the written word and manual graphic representation is common to the methods of text processing and written/graphic presentation (Cruikshank, Bainer \& Metcalf, 1995). More specifically, these methods include reading, writing and drawing (with other techniques of graphic representation). It goes without saying that these methods are necessarily used with the others, such as demonstration or the monologic method. The great advantage of using text processing and presentations is in its application to all of the school subjects and in all phases of work. However, the most important condition for the success of their use is the students' ability to use various materials. Therefore, the pupils with visual impairment, for instance, need to be provided with a substitution or additional assistance in working with text. When assigning pupils with a task, it is very important to ensure that all pupils understood what they should be doing (and encourage asking additional questions), giving them enough time to work in their own pace.
As noted previously, the diverse and purposeful use of all teaching methods described in this article is crucial for effective teaching that meets the demands of modern education. Research often stresses out the relevance of transition from monologic to dialogic method. One of the barriers to cooperation between pupils and to the participation of pupils with sensory impairments is the dominance of monologue which is naturally established by the power-relations in the classroom (Lyle, 2008). Additionally, many teachers don't have sufficient classroom management skills necessary for adequate planning of the available class time. This implies the relevance of empowerment and motivation of the teachers, as they are the main carrier of inclusion. They need to be directed towards concrete and practical guidelines for the variety of situations in the classroom, and be encouraged to update their knowledge (Meyer, 2002). Having in mind the strengths and weakness of each of the teaching methods, the context of their application in inclusive education and the relevance of balance in their use, the aim of this study was to examine the frequency of their use in Serbian inclusive practice. So far, there has not been a lot of similar studies based on systematic observation and that included pupils with sensory impairments. Answering this research question might lead to the greater understanding of the inclusive educational system, point to the potential problems and finally, produce concrete suggestions for improvement.

\section{METHOD}

The sample consisted of 16 elementary schools in the Republic of Serbia attended by pupils with sensory impairments $(\mathrm{N}=69)$. Schools were chosen according to the information about the number and distribution of enrolled pupils with sensory impairments. The study was conducted using systematic observation. One school class was equivalent to one observation unit, and one observation unit was separated additionally to the introductory, central and the final part of the class. 382 sixth and seventhgrade classes were observed in total, as seen in Table 1 .

Table 1. Observations per grade

\begin{tabular}{lccc}
\hline & Grade & f & \% \\
\hline Sixth & & 200 & 52,4 \\
Seventh & & 182 & 47,6 \\
\hline & Total & 382 & 100,0 \\
\hline
\end{tabular}


The sample of pupils with sensory impairments consisted of blind, partially blind, deaf and partially deaf

pupils. The structure of the sample is presented in Table 2 .

Table 2. Type of impairment

\begin{tabular}{lccc}
\hline & Type of impairment & f & \% \\
\hline Blind & 5 & 7,2 \\
Partially blind & 35 & 50,7 \\
Deaf & 12 & 17,4 \\
Partially deaf & 17 & 24,6 \\
\hline \multicolumn{2}{c}{ Total } & 69 & 100,0 \\
\hline
\end{tabular}

The systematic observation was used according to the protocol for recording the teaching process. It consists of instructions for documenting the classroom space adaptation, forms of communication, classroom organization and use of teaching methods tools. As such it was assessed as appropriate for the present research goal, i.e. for collecting data on the frequency of teaching methods.

\section{RESULTS}

In relation to the prevalence of teaching methods, the results are grouped into the following observation units: the class as a whole, introductory, central and the final part of the time. Looking at the whole class, the monologic method is predominantly used. The next most common method is the dialogue, being almost equally present as the monologue. Demonstration is the least frequently used teaching method. The percentage of method use is presented in Table 3. The methods used in the introductory part of the class are the monologue and the dialogue which are prevalent to an equal degree. Written/graphic presentation, working with text and demonstration are used to a significantly less extent. These results are not surprising, because the introduction usually serves to present new information or to reflect on previous work.

Table 3. Teaching methods in the class

\begin{tabular}{lccc}
\hline \multicolumn{1}{c}{ Type of impairment } & f & $\mathbf{\%}$ \\
\hline Blind & 5 & 7,2 \\
Partially blind & 35 & 50,7 \\
Deaf & 12 & 17,4 \\
Partially deaf & 17 & 24,6 \\
\hline \multicolumn{2}{c}{ Total } & 69 & 100,0 \\
\hline
\end{tabular}

The prevalence of methods in the introductory part of the class is presented in Table 4.

Table 4. Teaching methods in the introductory part of the class

\begin{tabular}{lccc}
\hline & Teaching methods & f & \% \\
\hline Monologue & & 174 & 45,5 \\
Dialogue & & 174 & 45,5 \\
Written/graphic presentation & & 14 & 3,7 \\
Working with text & 10 & 2,6 \\
Demonstration & Total & 10 & 2,6 \\
\hline
\end{tabular}

According to Table 5, the dialogue is the most frequent method used in the central part of the class. Monologue is used to a lesser extent, and written/graphic presentation follow. Demonstration and working with text are not used as often as other methods. 
Table 5. Teaching methods in the central part of the class

\begin{tabular}{lccc}
\hline & Teaching methods & f & \% \\
\hline Dialogue & & 140 & 36,6 \\
Monologue & 111 & 29,1 \\
Written/graphic presentation & & 86 & 22,5 \\
Working with text & & 33 & 8,6 \\
Demonstration & Total & 12 & 3,1 \\
\hline
\end{tabular}

In the final part of the class, the monologic method is predominant. Here, the dialogue is used significantly less, as well as the written/graphic presentation. Dem-

introductory part, a negligible little percentage of the time. The frequency of teaching methods in the final part of the class is present in Table 6 .

onstration and working with text take, similarly to the

Table 6. Teaching methods in the final part of the class

\begin{tabular}{lccc}
\hline & Teaching methods & f & \% \\
\hline Monologue & & 171 & 44,8 \\
Dialogue & & 135 & 35,3 \\
Written/graphic presentation & 41 & 10,7 \\
Working with text & & 24 & 6,3 \\
Demonstration & Total & 11 & 2,9 \\
\hline
\end{tabular}

The results clearly indicate that the monologic and dialogic method are methods which are prevalently used, while their combination is rarely applied. Other methods are used to a significantly less degree. Written/graphic presentation is used mostly in the central part of the class. Overall, it is visible that the data for the introductory part and the class as a whole is very similar, and that the central part of the class is the only part where dialogue is used more often than the monologue. Having in mind the critiques of traditional education, these findings are in accordance with its subject and the presented literature.

\section{DISCUSSION}

This study had the goal to investigate the prevalence of teaching methods in inclusive schools in Serbia that pupils with sensory impairments attend. The results show that the monologic method is predominantly used. The next most commonly used method is the dialogue. The difference in percentage between them is smaller when the observation is split into parts of the class, but looking at the class as a whole, the monologic method prevails. Additionally, these two forms of communication that naturally go together, are used separately in observed classes. The least frequent methods in all observational units are working with text, written/graphic presentation, and demonstration, respectively. These results suggest that the traditional approach is still prevalent in schools. Therefore, it is reasonable to question how many opportunities pupils have to fully engage in class, especially children with sensory impairments. The prevalence of monologue, with the negligible use of methods such as demonstration and text processing (i.e. those that consolidate knowledge) brings into consideration the general adaptation of class and the level of understanding pupils reach. The monologic method alone, regardless of its practicality, can neglect the social component of knowledge and distance all the agents of the class. Furthermore, despite the fact that the dialogue is used almost as much, it remains uncombined with monologue and other ways of processing material as well. The dialogic method and its diversity of application can undoubtfully be difficult for realization, but it should not be seen as a separate, or an "advanced" method because of that. Rather, it should serve as the connective tissue of class. The bidirectional communication can, therefore, be a starting point for the achievement of inclusion. 


\section{CONCLUSION}

In executing a curriculum that is time-limited in practice, the teachers have the task to use the material in such a way that all pupils achieve their educational goals, behave as a cooperative, close community and adapt to the needs of pupils with sensory impairments. For that reason, enhancing teachers' competencies and stimulating them to the teaching methods equally is necessary in inclusive practice. Future research could address the ways of upgrading the practice of teaching when pupils with sensory impairments attend class with others. Also, a more thorough analysis of the teaching methods from the pupils' point of view (if possible, a qualitative one). It can contribute to our understanding of how pupils react to patterns of communication in class, and how the methods can be accordingly approved. By researching and resolving these, as well as other important current issues of our educational system, researchers can also indirectly advance the society as a whole, in which each member is given the opportunity for a unique contribution and for the realization of personal potentials.

\section{REFERENCES}

Alexander, R.J. (2006) Towards Dialogic Teaching. New York: Dialogos.

Bligh, D. (1998). What's the use of lectures? Exeter: Intellect Books.

Booth, T, \& Ainscow, M. (2010). Приручник за инклузивни развој школе. Београд: Save the children: Завод за вредновање квалитета образовања и васпитања.

Buljubašić Kuzmanović, V. \& Petrović, A. (2014). Teaching and lesson design from primary and secondary teachers' perspective. Život i škola, 31, 76-90.
Burbules, N. C. (1993). Dialogue in teaching. Theory and practice. New York: Teachers College Press.

Cruickshank, D. R., Bainer, D. L., \& Metcalf, K. K. (1995). The act of teaching. USA, New York: McGraw-Hill.

Communication Access and Quality Education for Deaf and Hard-of-hearing Children (1999). The Report of the California Deaf and Hard-of-hearing Education Advisory Task Force. California: California Department of Education.

Egan, K. (1992). Imagination in Teaching and Learning. New York: Routledge.

Freire, P. (2000). Pedagogy of the oppressed. New York: Continuum.

Glasson, G. E. (1989). The effects of hands-on and teacher demonstration laboratory methods on science achievement in relation to reasoning ability and prior knowledge. Journal of Research in Science Teaching, 26, 121-131.

Jablan, B. \& Kovačević, J. (2008). Obrazovanje u redovnim školama i školama za decu ometenu u razvoju: zajedno ili paralelno. Nastava i vaspitanje, 1, 43-55.

Hoover, H. K. (1958). Teaching Methods of Teaching by Demonstration and Application. The Clearing House: A Journal of Educational Strategies, Issues and Ideas, 33, 90-91.

Lyle, S. (2008). Dialogic Teaching: Discussing Theoretical Contexts and Reviewing Evidence from Classroom Practice. Language and Education, 22, 222-240.

Meyer, H. (2002). Didaktika razredne kvake-rasprave o didaktici, metodici i razvoju škola. Zagreb: Eduka.

Pranjić, M. (2005). Didaktika. Zagreb: Golden marketing Tehnička knjiga.

Skidmore, D. (2000). From pedagogical dialogue to dialogical pedagogy. Language and Education 14, 283-296.

Terhart, E. (2001). Metode poucavanja i ucenja. Zagreb: Educa

Walsch, B. (2002). Kurikulum za 1. razred osnovne škole. Zagreb: Udruga Korak po korak.

Watkins, C. (2005) Classrooms as Learning Communities: What's in it for schools? London: Routledge. 